\title{
Immunoelectron microscopy study of superficial skin nerves in drug-induced acute urticaria*
}

\section{Estudo de microscopia imunoeletrônica dos nervos superficiais da pele na urticária aguda induzida por medicamentos}

\author{
Paulo Ricardo Criado ${ }^{1}$ \\ Cleusa F.H. Takakura ${ }^{3}$ \\ Mirian Nacagami Sotto ${ }^{5}$
}

\author{
Roberta Fachini Jardim Criado ${ }^{2}$ \\ Carla Pagliari ${ }^{4}$ \\ Cidia Vasconcellos ${ }^{6}$
}

ABstract: BaCKGROUND: Few studies have evaluated the ultrastructure of the superficial skin nerves in urticaria.

OвJEctivE: The objective of this study was to describe findings in superficial skin nerves in cases of drug-induced acute urticaria. Methods: Seven patients with drug-induced acute urticaria were included in the study. Skin biopsies were obtained from the urticarial lesion and from the apparently normal skin. The 14 fragments collected were processed for immunogold electron microscopy using single stains for antitryptase and anti-FXIIIa antibodies, as well as double immunogold labeling for both.

RESULTS: Some sections showed mast cells in the process of degranulation. Following double immunogold staining, $10 \mathrm{~nm}$ (FXIIIa) and $15 \mathrm{~nm}$ (Tryptase) gold particles were found together throughout the granules in mast cells, indicating that tryptase and FXIIII are located inside each one of the granules of these cells. Interestingly, we found strong evidence of the presence of tryptase and factor XIIIa in the superficial skin nerves of these patients, both in cases of urticarial lesions (wheals) and in the apparently normal skin.

Conclusions: Tryptase and FXIIIa are present in the superficial nerves of the skin in drug-induced acute urticaria. This is the first report of tryptase and FXIIIa expression in the superficial skin nerves of patients with urticaria. Tryptase may be participating in neural activation in these patients, while FXIIIa may be present in the nerves to guarantee the functional integrity of structures.

Keywords: Factor XIIIa; Mast cells; Neurons; Tryptases; Urticaria

Resumo: Fundamentos: Poucos autores têm estudado a ultraestrutura dos nervos superficiais na urticária.

OвJEтrvo: Descrever os achados nos nervos cutâneos superficiais em casos de urticária aguda induzida por medicamentos.

MÉToDos: Sete pacientes com urticária aguda induzida por medicamentos foram incluídos no estudo. Foram obtidas biopsias da pele da lesão urticariforme e da pele aparentemente normal. Os 14 fragmentos coletados foram processados usando imunomarcação com ouro para anticorpos anti-triptase e anti-FXIIIa separadamente, além da dupla imunomarcação com ambos anticorpos. A seguir as amostras foram submetidas à análise por microscopia imunoeletrônica.

ReSULTADOS: Alguns cortes demonstraram mastócitos em processo de degranulação. Após a imunomarcação dupla, partículas de ouro de $10 \mathrm{~nm}$ (FXIIIa) e partículas de ouro de $15 \mathrm{~nm}$ (Triptase) apresentavam-se juntas em grânulos de mastócitos indicando que a triptase e o FXIIIla se localizam dentro de cada um dos grânulos dessas células. Curiosamente, foi encontrada uma forte evidência da presença da triptase e do fator XIIIa nos nervos superficiais dos pacientes avaliados, tanto em lesões urticadas, como na pele aparentemente normal.

CONClusôES: A triptase e o FXIIIa estão presentes nos nervos superficiais da pele na urticária aguda medicamentosa. Este é o primeiro relato da expressão de triptase e de FXIIIa nos nervos superficiais na urticária. A triptase poderia estar participando da ativação neural nos pacientes estudados. O FXIIIa poderia estar presente nos nervos, com a finalidade de manter a integridade funcional dessas estruturas.

Palavras-chave: Fator XIIIa; Mastócitos; Neurônios; Triptases; Urticária

\footnotetext{
Received on 30.06.2011

Approved by the Advisory Board and accepted for publication on 25.07.2011.

* This study was conducted at the Dermatology Department, School of Medicine, São Paulo University (FMUSP), São Paulo, SP, Brazil

Conflict of interest: None

Financial funding: None

PhD. Dermatology Department, School of Medicine, São Paulo University (FMUSP), São Paulo, SP, Brazil.

Master's Degree, Dermatology and Allergy Unit, Faculdade de Medicina do ABC (FMABC), Santo André, SP, Brazil.

Biologist. Pathology Department, School of Medicine, São Paulo University (FMUSP), São Paulo, SP, Brazil.

PhD. Pathology Department, School of Medicine, São Paulo University (FMUSP), São Paulo (SP), Brazil.

$\mathrm{PhD}$ in Pathology. Dermatology Department, School of Medicine, São Paulo University (FMUSP), Brazil

PhD. Dermatology Department, School of Medicine, São Paulo University (FMUSP) and Universidade Cidade de São Paulo (UNICID), São Paulo, SP, Brazil.

CC2012 by Anais Brasileiros de Dermatologia
}

An Bras Dermatol. 2012;87(3):375-81. 


\section{INTRODUCTION}

The clinical features of urticaria are the result of local vasodilatation, increased blood flow and increased vascular permeability. Lymphatic drainage contributes by modulating the extent of the local edema. ${ }^{1}$ The degree to which the lesion develops depends on the severity of capillary leakage and the efficiency of the lymphatic vascular system in clearing it. ${ }^{1}$ The main site of increased vascular permeability is in the post-capillary vessels. ${ }^{2,3}$ Histamine is probably the principal mediator in this process via $\mathrm{H} 1$ and $\mathrm{H} 2$ receptors; however, its perpetuation is attributable to additional mediators such as prostaglandin D2 and leukotriene C4, which are vasodilators and cause increased vascular permeability. ${ }^{4,5}$ In addition, vascular endothelial growth factor (VEGF) increases the permeability of human endothelial cells in vitro.,

Tryptase is a serine protease that is contained almost exclusively in mast cell granules. ${ }^{7}$ Mast cell tryptase is a potent modulator of microvascular leakage and inflammatory responses during episodes of allergic reactions. ${ }^{8}$ Mast cell tryptase is one of the crucial molecules released by mast cells during inflammation and allergic reactions, and is involved in tissue repair. ' It is capable of cleaving many extracellular substrates involved in inflammation and tissue repair. Tryptase activates Proteinase-Activated Receptor-2 (PAR-2) in several cells, indicating that at least some of the tryptase-mediated effects in the skin may be induced via PAR-2 activation. ${ }^{9}$ Deleuran et al. studied tryptase levels in suction-blister fluid from patients with chronic urticaria, urticaria pigmentosa, cholinergic urticaria, urticarial dermographism, pruritus of unknown origin, eczema, psoriasis and atopic dermatitis, as well as from healthy controls. ${ }^{10}$ Those authors found tryptase levels $\leq 15 \mu \mathrm{g} / \mathrm{i}$ in blister fluid from controls and levels $>50 \mu \mathrm{g} /$ from patients with active urticaria. They concluded that patients with urticaria have mast cells that readily release tryptase both in areas of skin with lesions and in those without lesions.

A considerable number of reports suggest that tryptase and PAR-2 play a crucial role in cutaneous inflammation and hypersensitivity, mainly from the release of neuropeptides and cytokines from nerves and immunocompetent cells.

Furthermore, Schaumburg-Lever et al. previously reported having found FXIIIa (pro-transglutaminase) in mast cells. Over the past thirty years, it has become evident that the role of FXIIIa is not restricted solely to hemostasis but that, like other transglutaminases, it also determines cell shape by cross-linking the actin cytoskeleton and its related proteins, in addition to promoting cell adhesion and stabilizing extracellular matrices. ${ }^{11,12}$
To verify the presence of tryptase and FXIIIa in superficial nerves of the skin affected by urticarial lesions in vivo, drug-induced acute urticaria was selected as the model for this study.

\section{PATIENTS AND METHODS Subjects}

Seven patients with drug-induced acute urticaria (DIAU) were enrolled in the study. All patients were seen at the outpatient dermatology clinic of the teaching hospital, School of Medicine, University of São Paulo, Brazil.

\section{Inclusion and exclusion criteria}

Patients with DIAU who reported having taken medication between 1 and 14 days prior to the onset of urticaria and who had recovered following discontinuation of the suspected agent were enrolled in this study. Patients were followed up for a period of at least 3 months after recovery. A detailed history was taken of the patient's eating habits, occupational exposure to allergens, signs or symptoms of any active infectious disease and the presence of comorbidities. These factors were investigated whenever applicable to rule out other possible causes of urticaria. The diagnosis of drug-induced acute urticaria was made according to the criteria established by Moore et al. For safety and ethical reasons, provocation testing did not appear to be warranted, since in all cases the suspected drug was easily avoidable or could be changed to other non cross-reactive medication. Pregnant women, individuals under 18 years of age and patients with any concurrent cardiologic, respiratory, neurological, infectious or metabolic diseases were excluded from the study.

\section{Description of the patients}

Seven patients with drug-induced acute urticaria were enrolled to the study. The mean age of these patients was 38.7 years. Their clinical data are summarized in table 1.

\section{Techniques}

This study was approved by the Internal Review Board of the São Paulo University School of Medicine and the university teaching hospital under approval number $047 / 06$. All patients signed an informed consent form prior to being included in the study. It was impossible to establish the exact interval between the onset of urticaria and the time of the skin biopsies; however, this was estimated at a mean of 24-48 hours. Skin fragments from sun-protected areas of the trunk were obtained by a 6-mm punch biopsy using circular infiltration anesthesia with $2 \%$ lidocaine and no vaso- 
TABLE 1: Clinical and demographic data

\begin{tabular}{|c|c|c|c|c|c|}
\hline Patients & Sex & $\begin{array}{l}\text { Age } \\
\text { (years) }\end{array}$ & Ethnicity & $\begin{array}{l}\text { Urticaria } \\
\text { duration } \\
\text { (history) }\end{array}$ & Associated drugs \\
\hline Case 1 & $\mathrm{~F}$ & 42 & $\mathrm{C}$ & 4 weeks & potassium diclofenac \\
\hline Case 2 & $\mathrm{~F}$ & 55 & A & 3 weeks & $\begin{array}{l}\text { acetylsalicylic acid, dexchlorpheniramine, } \\
\text { phenylephrine and caffeine }\end{array}$ \\
\hline Case 3 & $\mathrm{~F}$ & 35 & $\mathrm{C}$ & 2 weeks & $\begin{array}{l}\text { acetylsalicylic acid, dexchlorpheniramine, } \\
\text { phenylephrine and caffeine }\end{array}$ \\
\hline Case 4 & $\mathrm{~F}$ & 29 & $\mathrm{C}$ & 8 days & potassium diclofenac \\
\hline Case 5 & $\mathrm{~F}$ & 29 & $\mathrm{C}$ & 3 days & ferrous sulfate \\
\hline Case 6 & $\mathrm{~F}$ & 32 & A & 7 days & $\begin{array}{l}\text { sodium dipyrone, ranitidine, hyoscine, } \\
\text { dimenhydrinate, pyridoxine, ascorbic acid } \\
\text { and chlorpheniramine }\end{array}$ \\
\hline Case 7 & $\mathrm{~F}$ & 49 & A & 4 weeks & $\begin{array}{l}\text { sodium dipyrone and potassium } \\
\text { diclofenac }\end{array}$ \\
\hline
\end{tabular}

Legend: F, female; C, Caucasian; A, of African descent.

constrictor, followed by hemostasis using a 4.0 Mononylon ${ }^{\circledR}$ suture. Biopsies were taken from the wheal and from the apparently normal skin (at least $5.0 \mathrm{~cm}$ from the biopsied wheal). The fourteen fragments collected were processed for immunoelectron microscopy (IMEM) and fixed in $0.2 \%$ glutaraldehyde (Sigma ${ }^{\circledR}$, No.G-5882, Sigma-Aldrich Corp., St Louis, MO, USA) /4\% paraformaldehyde (LADD no 5-55080) in $0.1 \mathrm{M}$ phosphate buffer $(\mathrm{pH} 7.4)$ with $2.5 \%$ of sucrose for 2 hours.

\section{Tissue Embedding:}

The material was washed twice in $0.1 \mathrm{M}$ phosphate buffer, $\mathrm{pH} 7.4$, dehydrated in ethanol $50 \%$ for 5 minutes, $70 \%$ for 7 minutes, $90 \%$ twice for 10 minutes and $100 \%$ ethanol twice for 15 minutes. Samples were then soaked in alcohol $100 \%$ containing acrylic resin LR White Resin (London Resin Company Ltd) twice for 10 minutes. The material was then embedded in pure LR White resin, making nine changes. After this, it was included in gelatin capsules with pure resin and polymerized in the oven at $52^{\circ} \mathrm{C}$ for three days.

\section{Ultratbin sections:}

The 70-nm thick sections were obtained using an ultra microtome and then collected in 300 mesh nickel screens, covered with FORMVAR pellicles (LADD - USA).

\section{Immunoelectron microscopy Single immunoelectron microscopy Immunostaining for FXIIIa:}

After completion of the above-mentioned procedures, the screens containing the sections were incubated with Tris-buffered saline (TBS) $0.05 \mathrm{M}, \mathrm{pH}$
7.2, twice for 5 minutes and then incubated in Trisbuffered saline (TBS) with $3 \%$ bovine serum albumin (BSA) at pH 7.2 for 5 minutes. Subsequently, the TBS was drained on Whatman filter paper and the screens were incubated for 30 minutes at room temperature with normal goat serum (NGS, dilution 1:30). Next, the NGS was drained without washing and the screens were incubated with primary polyclonal antibody antifactor XIII (Calbiochem) (1:100) diluted in $0.05 \mathrm{M}$ TBS pH 7.2 with $3 \%$ BSA overnight at $4^{\circ} \mathrm{C}$ (Table 2). Later, they were washed in $0.05 \mathrm{M}$ TBS with $1 \% \mathrm{BSA}$ plus $0.1 \%$ Tween 20 four times for 5 minutes. After that, the screens containing the sections were incubated in TBS with 1\% BSA ( $\mathrm{pH} 8.2)$ for 30 minutes at room temperature.

Next, the screens were incubated with the secondary antibody, goat anti-rabbit IgG, gold-labeled with colloidal gold particles of $10 \mathrm{~nm}$ in diameter (Electron Microscopy Sciences - USA) and diluted 1:20 in TBS buffer with $1 \% \mathrm{BSA}, \mathrm{pH} 8.2$. Incubation was 1 hour at room temperature. The screens were then washed in TBS with $0.05 \%$ BSA and $0.1 \%$ Tween 20 (pH 7.2) four times for 5 minutes and then in TBS con-

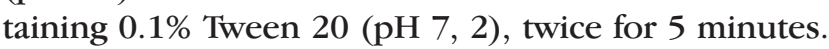
Finally, the screens were washed three times in distilled water for 2 minutes and sections were fixed in $2 \%$ aqueous glutaraldehyde solution for 10 minutes. Contrast was achieved using uranyl acetate and lead citrate and grids were observed under a transmission electron microscope JEOL 1010 at the Department of Pathology, Medical School, University of São Paulo.

\section{Immunostaining for Tryptase:}

The same procedures used for the FXIII immunostaining were used for tryptase. In this case, 
TABLE 2: Primary antibodies used in immunohistochemical and immunoelectron microscopy studies

\begin{tabular}{llll}
\hline & $\begin{array}{l}\text { Monoclonal (M) or } \\
\text { Polyclonal (P) }\end{array}$ & Source & \multicolumn{1}{c}{$\begin{array}{l}\text { Dilution } \\
\text { (immunoelectron microscopy) }\end{array}$} \\
\hline Tryptase & $\begin{array}{l}\text { M (AAA3) } \\
\text { (mouse anti-human) }\end{array}$ & $\begin{array}{l}\text { DAKO, Carpinteria, } \\
\text { CA, USA }\end{array}$ & $1: 200$ \\
Factor XIIIa (FXIIIa) & $\begin{array}{l}\text { P } \\
\text { (rabbit anti-human) }\end{array}$ & $\begin{array}{l}\text { Calbiochem, La Jolla, } \\
\text { CA, USA }\end{array}$ & $1: 100$ \\
\hline
\end{tabular}

Legend: M, monoclonal; P, polyclonal.

monoclonal mouse anti-human mast cell tryptase (DAKO, Carpentaria, CA, USA) diluted 1:200 was used as the primary antibody. Goat anti-mouse IgG, goldlabeled with colloidal gold particles of $15 \mathrm{~nm}$ in diameter was used as a secondary antibody (Electron Microscopy Sciences - USA) diluted 1:20 in TBS buffer with $1 \% \mathrm{BSA}, \mathrm{pH}$ 8.2. The mixture was incubated for 1 hour at room temperature. All solutions were filtered with Millipore filter $0.22 \mu \mathrm{m}$.

\section{Double immunostaining protocol:}

Incubations were performed using the procedures previously described for the single reactions. Incubation with primary antibodies was carried out using a mixture of two antibodies diluted in TBS plus BSA 3\% $0.05 \mathrm{M}$ (dilutions were 1:100 and 1:200, respectively, for Factor XIII and tryptase). Incubation with secondary antibodies was performed by diluting goat anti-mouse IgG and goat anti-rabbit IgG in TBS $0.05 \%$ plus BSA 1\% 1:20. These procedures were adapted from those established by Craig et al. ${ }^{14}$

\section{RESULTS}

\section{Clinical aspects}

Urticarial lesions consisted of wheals randomly distributed all over the skin, with lesions varying in size from $3 \mathrm{~mm}$ to $8 \mathrm{~cm}$ in diameter. The genital region and the scalp were spared in all cases. The symptoms were referred to by patients as a stinging, burning or itching sensation.

\section{Transmission Immunoelectron Microscopy}

\section{Single Immunoelectron Microscopy}

\subsection{General aspects}

When the sections consisting of material removed from wheals were examined under transmission immunoelectron microscopy, a slight vascular dilatation was seen, with platelets, red blood cells and leukocytes in the vessel's lumen, and mast cells, polymorphonuclear cells, lymphocytes and dendritic cells close to the vessels. There were few normal-looking mast cells, with the others being granule-depleted. In some areas, mast cells, macrophages, lymphocytes and satellite dendritic cells were closely associated (Figure 1). Some macrophages were full of melanin. A variable number of eosinophils and polymorphonuclear neutrophils were observed, and the presence of lymphocytes and macrophages was significant. The epidermis and the basal membrane zone were preserved. Mast cell granules were found in the cytoplasm and extruded mast cell granules were found between dermal collagen fibers showing immunolabeled tryptase and FXIIIa (Figure 2).

\subsection{Superficial nerves}

In some sections of material from urticarial lesions and some from apparently normal skin, some perineurial cells (P) surrounding a Schwann cell/axonal complex were found in small (superficial) nerves of the dermis. The complex did not include the nucleus, and consisted of bundles of axons (A) enveloped by Schwann cytoplasm (S) (Figure 3). The basal lamina

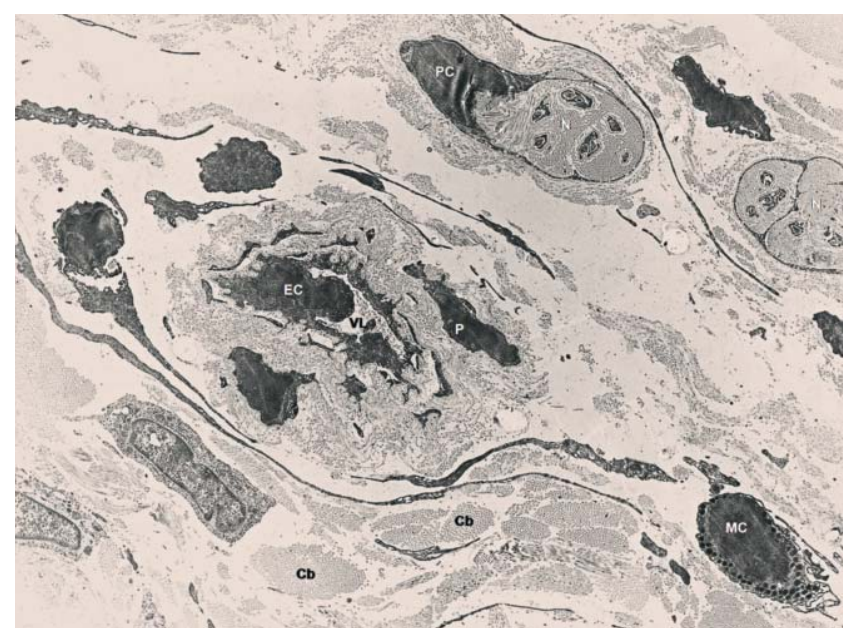

FIGURE 1: Dermal microvascular unit in drug-induced acute urticaria (DIAU) - Capillary vessel with an endothelial cell (EC) showing a prominent nucleus directed towards the vascular lumen (VL). Note the mast cells $(\mathrm{MC})$, collagen bundles $(\mathrm{Cb})$ and dermal nerves $(\mathrm{N})$ around the vessel, one of which is enclosed by a perineurial cell (PC) (Immunoelectron transmission microscopy, original magnification $5,000 x)$ 

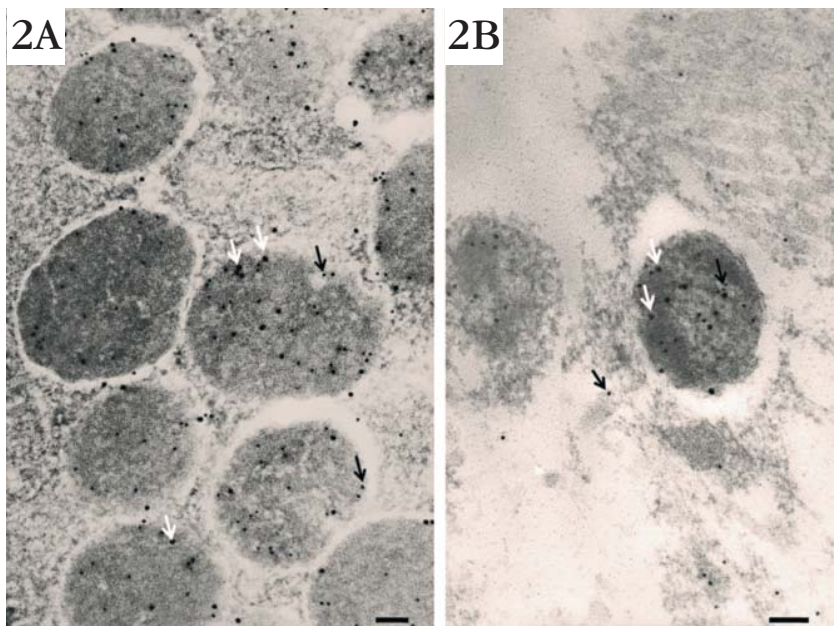

Figure 2: Mast cell granules in urticaria lesion. A: Mast cell showing immunolabeled granules (double immunoelectron microscopy, original magnification 125,000x). B: Extruded mast cell granules dissolving into the dermis. Immunolabeled tryptase (white arrow) and immunolabeled FXIIIa (black arrow) were found in both intracytoplasmic and extruded granules (double immunoelectron microscopy, original magnification 150,000x). (Black bars $=100 \mathrm{~nm}$ )

was ill defined, being indiscernible at some segments of the Schwann cell plasma membrane. This occurred because the sections were not treated with osmium tetroxide in order to improve visualization of the gold particles under the transmission immunoelectron microscopy. An appreciable amount of endoneurial collagen (E) was present.

Perineurial cells were flattened in appearance with prominent nuclei. The cytoplasm narrowed considerably to become an elongated fine process that enclosed the nerve.

\section{Double immunoelectron microscopy}

In the small nerves of the dermis around dermal vessels, the presence of immunolabeled tryptase and FXIIIa was found in sections containing material both from apparently normal skin and from urticarial lesions at immunoelectron transmission microscopy (Figure 2). Some extruded mast cell granules around the nerves showed tryptase $(15 \mathrm{~nm})$ and FXIIIa immunolabeling $(10 \mathrm{~nm})$ (Figure 2).

Both tryptase $(15 \mathrm{~nm})$ and FXIIIa $(10 \mathrm{~nm})$ gold particles were dispersed on endoneurial collagen and axons (Figures 3, 4 and 5). This was found in all seven cases, in sections from both apparently normal skin and urticarial lesions.

\section{DISCUSSION}

Small nerves of the dermis around dermal vessels showing immunolabeled tryptase and FXIIIa were found in sections containing material from urticarial lesions and from apparently normal skin. The obser-

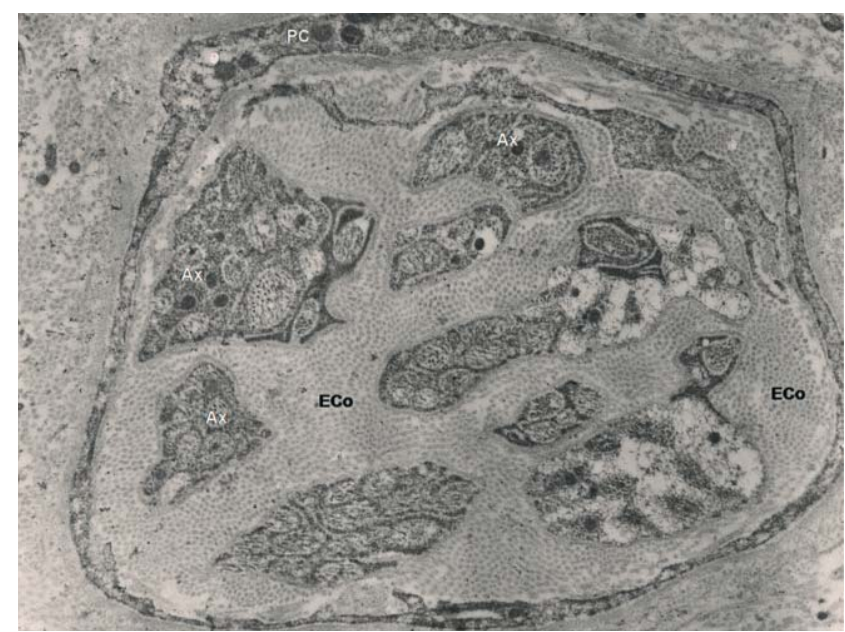

Figure 3: Dermal nerve in drug-induced acute urticaria (DIAU) The cytoplasm of a perineurial cell (PC) encloses the endoneurial collagen (Eco) and the axons (A) (double immunoelectron microscopy, original magnification $20,000 x$ )

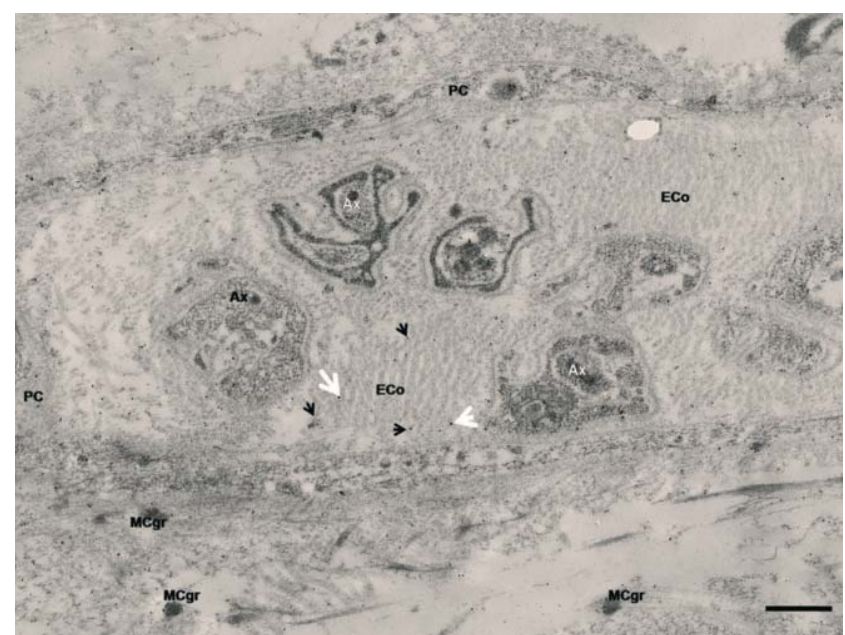

FIGURE 4: Dermal nerve in drug-induced acute urticaria (DIAU) The cytoplasm of a perineurial cell (PC) encloses the endoneurial collagen (Eco) and the axons (A). Note the extruded mast cell granules (MCgr) in the vicinity of the dermal nerve showing double immunolabeled tryptase (white arrow) and immunolabeled FXIIIa (black arrow) (double immunoelectron microscopy, original magnification 30,000x), (black bar $=500 \mathrm{~nm}$ )

vation of similar findings both in hives lesions and in the adjacent, apparently normal skin can be understood as a global activation of the skin in these patients. That means that even in areas where the wheals are still not visible, they can already be detected at ultrastructural level by the presence of the mast cell degranulation process.

To the best of our knowledge, this is the first time that tryptase and FXIIIa have been shown under transmission immunoelectron microscopy in superficial nerves of the skin of patients with urticaria. This 

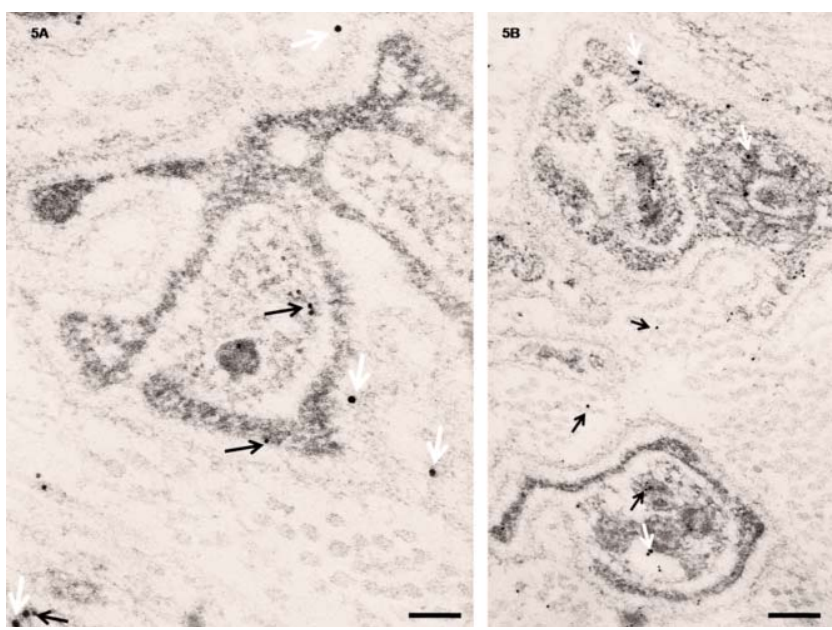

Figure 5: Dermal nerve in drug-induced acute urticaria (DIAU) - 5A Detail of the cross-section of the dermal nerve showing double immunolabeled tryptase (white arrow) and immunolabeled FXIIIa (black arrow), both in the endoneurial collagen and axons (double immunoelectron microscopy, original magnification 200,000x) (black bar $=100 \mathrm{~nm}) .5 \mathrm{~B}$. Detail of a cross-section of the dermal nerve showing double immunolabeled tryptase (white arrow) and immunolabeled FXIIIa (black arrow), both in the endoneurial collagen and axons (double immunoelectron microscopy, original magnification 100,000x), (black bar $=200 \mathrm{~nm}$ )

finding may represent morphological evidence of neuronal stimulation by mast cell mediators (tryptase) in urticaria, which could contribute to neurogenic inflammation.

Considering that tryptase is the most abundant protein stored in human mast cell granules and that mast cell degranulation will, therefore, lead to the release of large amounts of the protease, tryptase is likely to have a profound effect on any condition in which mast cell degranulation is a component. As mast cell degranulation predominantly occurs during inflammatory conditions, tryptase may be expected to play a role in the regulation of inflammatory responses. ${ }^{15}$ In humans, proteinase-activated receptor-2 (PAR-2) is also expressed by dermal immunocompetent cells, which so far have not been characterized, and by dermal sensory nerves. ${ }^{16}$ The observation that PAR-2 agonists (e.g. tryptase) are involved in the transmission of neurogenic inflammation and pain subsequently raises the question of whether PAR-2 may be involved in the central transmission of pruritus. ${ }^{17}$ Itching is one of the most frequent symptoms in dermatological diseases, accompanying inflammatory and immune responses to several diseases such as hypersensitivity reactions or urticaria, for example. ${ }^{16}$

As shown in the case of many organs, serine proteases such as thrombin, cathepsin G, tryptase and trypsin are capable of cleaving PARs to induce widespread inflammation that is characterized by vasodilatation, extravasation of plasma proteins and infiltration of neutrophils, events that are present in urticarial lesions. ${ }^{17}$ Moreover, tryptase-releasing mast cells can be found in close proximity to PAR-2-expressing cells such as keratinocytes and dermal endothelial cells or C fibers during inflammation. ${ }^{18-21}$

In this study, morphological evidence was found of the presence of tryptase in dermal nerves in patients with drug-induced acute urticaria. Furthermore, FXIIIa expression was found in dermal nerves. Monsonego et al. studied plasma, macrophages and optic nerves from fish (Cyprinus carpio) and found a $55 \mathrm{kDa}$ form of transglutaminase that cross-reacts immunologically with the a-subunit of FXIII in mammals $(80 \mathrm{kDa}) .^{22}$ Analysis of FXIIIa expression in mammalian neural tissues and their response to injury showed high levels of the enzyme in media conditioned by peripheral nerves as compared with media conditioned by nerves from the central nervous system. ${ }^{22}$ The cellular source of the FXIIIa found in nerve tissue may be macrophages resident in normal nerve tissue (i.e., microglia) and/or macrophages that have invaded the tissue following injury. ${ }^{22}$ The possibility that glial cells (Schwann cells) or neurons in nerve tissue also express the enzyme requires further immunohistochemical and cytochemical investigation.

\section{CONCLUSION}

It is reasonable to assume that in dermal nerves FXIIIa may participate in the repair process during nerve injuries following mast cell degranulation, and that FXIIIa discharged from mast cells may contribute to the tissue source of FXIIIa in dermal nerves. 


\section{REFERENCES}

1. Sabroe RA, Greaves MW. What is urticaria? Anatomical, physiological, and histological considerations and classification. In: Greaves MW, Kaplan AP, editors. Urticaria and Angioedema. New York: Marcel Dekker Inc; 2004. p.1-50.

2. Majno G, Gilmore V, Leventhal M. On the mechanism of vascular leakage caused by histamine-type mediators. A microscopic study in vivo. Circ Res. 1967;21:833-47.

3. Camp RD, Coutts AA, Greaves MW, Kay AB, Walport MJ. Responses of human skin to intradermal injection of leukotrienes C4, D4 and B4. Br J Pharmacol. 1983;80:497-502.

4. Soter NA, Lewis RA, Corey EJ, Austen KF. Local effects of synthetic leukotrienes (LTC4, LTD4, LTE4, and LTB4) in human skin. J Invest Dermatol. 1983;80:115-9.

5. Hippenstiel S, Krüll M, Ikemann A, Risau W, Clauss M, Suttorp N. VEGF induces hyperpermeability by a direct action on endothelial cells. Am J Physiol. 1998:274:L678-84.

6. Nagy JA, Benjamin L, Zeng H, Dvorak AM, Dvorak HF. Vascular permeability, vascular hyperpermeability and angiogenesis. Angiogenesis. 2008;11:109-19.

7. Schwartz LB. Tryptase, a mediator of human mast cells. J Allergy Clin Immunol. 1990;86:594-8

8. He S, Walls AF. Human mast cell tryptase: a stimulus of microvascular leakage and mast cell activation. Eur J Pharmacol. 1997;328:89-97.

9. Moormann C, Artuc M, Pohl E, Varga G, Buddenkotte J, Vergnolle N, et al. Functional characterization and expression analysis of the proteinase-activated receptor-2 in human cutaneous mast cells. J Invest Dermatol. 2006;126:746-55

10. Deleuran B, Kristensen M, Larsen CG, Matsson P, Enander I, Andersson AS, et al. Increased tryptase levels in suction-blister fluid from patients with urticaria. $\mathrm{Br} \mathrm{J}$ Dermatol. 1991;125:14-7.

11. Schaumburg-Lever G, Gehring B, Kaiserling E: Ultrastructural localization of factor XIlla. J Cutan Pathol. 1994;21:129-34.

12. Adany R, Bardos H, Antal M, Modis L, Sarvary A, Szucs S, et al. Factor XIII of blood coagulation as a nuclear crosslinking enzyme. Thromb Haemost. 2001;85:845-51.

13. Moore N, Biour M, Paux G, Loupi E, Begaud B, Boismare F, et al. Adverse drug reaction monitoring: doing it the French way. Lancet. 1985;9:1056-8.

14. Craig SS, Schechter NM, Schwartz LB. Ultrastructural analysis of human T and TC mast cells identified by immunoelectron microscopy. Lab Invest. 1988;58:682-91.
15. Hallgren J, Pejler G: Biology of mast cell tryptase. An inflammatory mediator. FEBS J. 2006;273:1871-95.

16. Steinhoff M, Buddenkotte J, Shpacovitch V, Rattenholl A, Moormann C, Vergnolle N, et al. Proteinase-activated receptors: transducers of proteinase-mediated signaling in inflammation and immune response. Endocr Rev. 2005;26:1-43.

17. Roosterman D, Goerge T, Schneider SW, Bunnett NW, Steinhoff M. Neuronal control of skin function: the skin as a neuroimmunoendocrine organ. Physiol Rev. 2006;86:1309-79.

18. Hou L, Kapas S, Cruchley AT, Macey MG, Harriott P, Chinni C, et al. Immunolocalization of protease activated receptor-2 in skin: receptor activation stimulates interleukin- 8 secretion by keratinocytes in vitro. Immunology. 1998;94:356-62.

19. Brain SD. Sensory neuropeptides: their role in inflammation and wound healing Immunopharmacology. 1997;37:133-52.

20. Brain SD and Williams TJ. Inflammatory oedema induced by synergism between calcitonin gene-related peptide (CGRP) and mediators of increased vascular permeability. Br J Pharmacol. 1985;86:855-60

21. Brain SD and Williams TJ. Neuropharmacology of peptides in skin. Semin Dermatol. 1988;7:278-83

22. Monsonego A, Mizrahi T, Eitan S, Moalem G, Bárdos H, Adány R, et al. Factor XIIla as a nerve-associated transglutaminase. FASEB J. 1998;12:1163-71.
MAILING ADDRESS:
Paulo Ricardo Criado
Rua Carneiro Leão 33 Vila Scarpelli
04050-430 Santo André, SP
E-mail:prcriado@uol.com.br

How to cite this article: Criado PR, Criado RFJ, Takakura CFH, Pagliari C, Sotto MN, Vasconcellos C. Immunoelectron microscopy study of superficial nerves of the skin in drug-induced acute urticaria. An Bras Dermatol. 2012;87(3):375-81. 